\title{
Presence and stability of B complex vitamins in bee pollen using different storage conditions
}

\author{
Vanilda Aparecida Soares de Arruda ${ }^{\mathrm{a}}$, Aline Aparecida Santos Pereira ${ }^{\mathrm{a}}$, Leticia M. Estevinho ${ }^{\mathrm{b}, *}$, \\ Ligia Bicudo de Almeida-Muradian ${ }^{a}$ \\ ${ }^{a}$ Laboratory of Food Analysis, Department of Food and Experimental Nutrition, Pharmaceutical Science School, University of São Paulo, Av. Prof. Lineu Prestes, \\ 580, Bloco 14, Cidade Universitária, CEP 05508-900, São Paulo, SP, Brazil \\ ${ }^{\mathrm{b}}$ CIMO-Mountain Research Center, Agricultural College of Bragança, Polytechnic Institute of Bragança, Campus Santa Apolónia, E $5301-855$ Bragança, Portugal
}

\section{A R T I C L E I N F O}

\section{Article history:}

Received 15 July 2012

Accepted 16 September 2012

Available online 25 September 2012

\section{Keywords:}

Dehydrated bee pollen

Vitamins

B vitamins

Food analysis

Bee products

\begin{abstract}
A B S T R A C T
This study has the objective of evaluating the stability of B complex vitamins and its vitamers, for a period of 1 year of storage. The pollen samples were stored under room temperature (with and without light) and frozen. The vitamins were quantified by HPLC with fluorescence detection. All proposed vitamins were found in the samples and the dehydration process did not interfere in vitamin content. The variations were (dry basis): 0.59-1.09 mg/100 $\mathrm{g}\left(\mathrm{B}_{1}\right) ; 1.73-2.56\left(\mathrm{~B}_{2}\right) ; 6.43-15.34(\mathrm{PP})$ and $0.33-0.68\left(\mathrm{~B}_{6}\right)$. After 1 year of storage, it can be stated that vitamin $B_{1}$ concentration remained constant, while for the others, the concentration loss was dependent on time rather than on storage conditions. All samples were considered vitamin $B_{2}$ sources. The influence of the storage time in the concentrations of vitamin $\mathrm{B}_{6}$ and $\mathrm{PP}$ was explained mathematically, through linear regression equations of multivariate analysis.
\end{abstract}

(C) 2012 Elsevier Ltd. All rights reserved.

\section{Introduction}

Bee pollen is a mixture of flower pollen, nectar and bee secretions. It can be collected by beekeepers without damage to the beehive. This natural product, that has been gaining prominence, is recognized to be a valuable apitherapeutic product with potential for medical and nutritional applications (Almeida-Muradian et al., 2005). In fact it contains proteins, the 22 basic amino acids, carbohydrates, lipids, vitamins and minerals (Morais et al., 2011). Basically, it contains vitamins of B complex, vitamin C-E. As in other protein-rich foods, pollen can quickly lose its nutritional value if handled or stored incorrectly (Bogdanov, 2004). To ensure the quality and identity of the product, the Brazilian legislation (Brazil, 2001) established standards, even though the pollens' expiration date is currently neglected. Other countries such as Bulgaria (Bulgarian Standard 2567111-91); Poland (PN-R-78893 “Obnóza pylkowe") and Switzerland (Swiss Food Manual: Pollen Bienenprodukte, BAG - Swiss Federal Office for Public Health) have also established quality standards for this product.

Since bee pollen presents a high level of moisture in its composition, a dehydration process is necessary, to avoid rapid fermentation and spoilage (Estevinho et al., 2012). This process is, consequently, crucial in the enlargement of the shelf life time.

\footnotetext{
* Corresponding author. Tel.: +351 273303342.

E-mail address: leticia@ipb.pt (L.M. Estevinho).
}

Barreto et al. (2006), when assessing the shelf life of dried bee pollen, concluded that it varies depending on storage temperature and, furthermore, that the physical and chemical analysis should be complemented with organoleptic analysis. By the sensorial analysis, the pollen became unfit for consumption in 240 days at room temperature (annual average $25.81^{\circ} \mathrm{C}$ ), undergoing a process of darkening and turning bitter by Maillard reaction. The samples stored at $-12{ }^{\circ} \mathrm{C}$ presented the greatest durability, being rejected after 360 days. Regarding the physical and chemical analysis, the pollen samples remained within the parameters established in the legislation in force, except for free acidity and total sugars.

Due to the nutritional and functional importance of the components present in foods, it is necessary to control and supervise the different development processes, in order to ensure that the processed foods supply consumers with all nutrients in their most available form, comply with their requirements and maintain their organoleptic proprieties (Torres et al., 2003).

In an original form, the present study aimed to assess the stability of the $B$ complex vitamins $\left(B_{1}, B_{2}, B_{6}\right.$ and $\left.P P\right)$ including their vitamers, in samples of bee pollen after processing and during a 1 -year storage period. This comprehensive study is very important, as this group of vitamins plays a key role in the production of cellular energy $\left(B_{1}, B_{2}\right)$, facilitates the amino acid metabolism $\left(B_{6}\right)$ and helps the body converting carbohydrates into glucose (PP). As far as we know, this is the first work concerning this issue. 


\section{Materials and methods}

\subsection{Materials}

Seven different batches of fresh and dry bee pollen, recently produced, were acquired directly from PRONATU Lab. Produtos Naturais Ltda. (natural products laboratory). The team decided to use mixed pollen because it is the way the product is commonly sold, as it would too expensive for beekeepers to separate the pollen into families before selling it. This is very important since it's our intention to have results with potential use in the industry and not only theoretical approaches. The samples were collected from the Mata Atlântica area, in Vale do Ribeira-São Paulo State, Brazil. The collecting process took place from October 08 to November 30 , 2007, with a week interval between batches. Fifteen Apis mellifera bee hives were used. The supplier homogenized the collected batch, removed approximately $200 \mathrm{~g}$ in natura, which were kept in the freezer, and processed the remaining amount to a drying process in kiln from the brand Ballardin ${ }^{\circledR}$, adjusted to $45{ }^{\circ} \mathrm{C}$ temperature for approximately $6 \mathrm{~h}$. The processed bee pollen was stored in transparent plastic packages of $45 \mathrm{~g}$, labeled in accordance with the business procedures of the company. For the experiment, the batches were coded with the alphabet letters ( $G$ $\mathrm{L}, \mathrm{e}, \mathrm{M})$. The fresh bee pollen batches were analyzed immediately upon receipt and the dried bee pollen batches were divided as follows: 04 packages were analyzed immediately upon receipt to make up Time 0;04 packages were stored in freezer $\left(-18^{\circ} \mathrm{C}\right) ; 04$ packages were stored at room temperature (average $25^{\circ} \mathrm{C}$ ) exposed to light (F40W T12 lamp); 04 packages were stored at room temperature (average $25^{\circ} \mathrm{C}$ ), protected with aluminum foil from light exposure. The batches were stored under the three described conditions for a 1-year period and were analyzed at intervals of 4 months following acquisition (Times 1-3).

The standards employed for the analysis were acquired from the brand Merck. The solvents and other reagents used in the analysis were acquired from the brands Synth, Merck and Vetec.

\subsection{Methods}

2.2.1. Simultaneous extraction of vitamins $B_{1}, B_{2}$, vitamers of vitamin $B_{6}$ and niacin

The simultaneous extraction of the vitamins was performed as described by Moreschi (2006), Presoto and Almeida-Muradian (2008) and Arruda (2009), who prescribed the use of acid hydrolysis followed by enzymatic treatment with fungal diastase. In Erlenmeyer, approximately $5 \mathrm{~g}$ of bee pollen were mixed with $50 \mathrm{~mL}$ of $\mathrm{HCl} 0.1 \mathrm{~mol} / \mathrm{L}$ and kept in boiling water bath for $30 \mathrm{~min}$. After cooling to room temperature, the solutions had their $\mathrm{pH}$ adjusted to 4.6 with sodium acetate $2.5 \mathrm{M}$. After adding $0.5 \mathrm{~g}$ of fungal diastase enzyme (Merck) the solutions were incubated for $2 \mathrm{~h}$ at $42{ }^{\circ} \mathrm{C}$ in water bath. After the enzymatic treatment and the cooling to room temperature, the solutions were transferred to $100 \mathrm{~mL}$ volumetric flasks; the volumes were completed with deionized water; homogenized and filtered with paper filter and in $0.45 \mu \mathrm{m}$ membrane for injection into the chromatograph.

2.2.2. Chromatographic conditions for the analysis of $B$ complex vitamins in bee pollen The chromatographic conditions varied for each vitamin. The $B_{1}$ and $B_{2}$ vitamins were analyzed under the same conditions, while the $\mathrm{B}_{6}$ and PP vitamins were quantified in different chromatographic conditions. For all the cases, the temperature of the column used for the analytical procedures was $20^{\circ} \mathrm{C}$.

The vitamins $B_{2}$ and $B_{6}$ are detected directly by fluorescence, while vitamins $B_{1}$ and $\mathrm{PP}$ undergo pre and post column reaction respectively to be also detected by fluorescence.

\subsubsection{Determination of thiamine (vitamin $B_{1}$ ), with pre-column reaction}

2.2.3.1. Conversion of thiamine in thiochrome through pre-column reaction. For the conversion reaction of thiamine in thiochrome, $1 \mathrm{~mL}$ of standard solution diluted or from the sample extract was pipetted into $10 \mathrm{~mL}$ amber volumetric flasks, and approximately $2 \mathrm{~mL}$ of deionized water and $3 \mathrm{~mL}$ of potassium ferricyanide in basic medium were added. The mixture was homogenized and put to rest for 2 min to allow reaction. After this period, $450 \mu \mathrm{L}$ of $85 \%$ orthophosphoric acid were added. The solution was then cooled and the final volume was completed with deionized water. These solutions were filtered in $0.45 \mu \mathrm{m}$ membrane and injected into the chromatograph immediately after preparation.

The chromatographic method of analysis was based on procedure described by Ollilainen et al. (1993), Presoto and Almeida-Muradian (2008) and Arruda (2009). For the separation, $20 \mu \mathrm{L}$ were injected into column $\mathrm{C}_{18}$ reversed-phase column RP-18 spherical $5 \mu \mathrm{m} / 250 \times 4.6 \mathrm{~mm}$ with pre-column $5 \mu \mathrm{m} / 10 \times 4.6 \mathrm{~mm}$ Shimpack VP-ODS. The mobile phase was composed of phosphate buffer pH 7.2 (0.228\% $\mathrm{KH}_{2} \mathrm{PO}_{4} \cdot 3 \mathrm{H}_{2} \mathrm{O}$ ) and Dimethylformamide (85:15); flow: $1 \mathrm{~mL} / \mathrm{min}$; detected by fluorescence: Ex $368 \mathrm{~nm}$; Em $440 \mathrm{~nm}$.

\subsubsection{Determination of riboflavin (vitamin $B_{2}$ )}

The analysis method was based on procedure described by Augustin (1984), Presoto and Almeida-Muradian (2008) and Arruda (2009). For the separation, $20 \mu \mathrm{L}$ were injected into column $\mathrm{C}_{18}$ reversed-phase RP-18 spherical $5 \mu \mathrm{m} / 250 \times 4.6 \mathrm{~mm}$ with pre-column $5 \mu \mathrm{m} / 10 \times 4.6 \mathrm{~mm}$ Shim-pack VP-ODS. The mobile phase was composed of phosphate buffer $\mathrm{pH} 7.2\left(0.228 \% \mathrm{KH}_{2} \mathrm{PO}_{4} \cdot 3 \mathrm{H}_{2} \mathrm{O}\right)$ and dimethylformamide (85:15); flow: $1 \mathrm{~mL} / \mathrm{min}$; detected by fluorescence: Ex $450 \mathrm{~nm}$; Em $530 \mathrm{~nm}$.

\subsubsection{Determination of vitamin PP through niacin and niacinamide vitamers}

The analysis procedure was based on the description by Lahély et al. (1999), Presoto and Almeida-Muradian (2008) and Arruda (2009). PP vitamin was detected by fluorescence after reaction under ultraviolet (UV). For the separation, $20 \mu \mathrm{L}$ were injected into column $C_{18}$ reversed-phase Luna C18, spherical $5 \mu \mathrm{m} / 250 \times 4.6 \mathrm{~mm}$ with pre-column $5 \mu \mathrm{m} / 10 \times 10 \mathrm{~mm}$, brand Phenomenex. The mobile phase was composed of phosphate buffer $\left(0.954 \% \mathrm{KH}_{2} \mathrm{PO}_{4}\right)$ in solution of $0.76 \%$ hydrogen peroxide $30 \%$ and $0.1 \%$ of solution of copper sulphate $5 \mathrm{mM}$; flow: $1.5 \mathrm{~mL} / \mathrm{min}$; reactor composed of $12 \mathrm{~m}$ of tetrafluoroethylene (TFE) tubing, $0.5 \mathrm{~mm}$ internal diameter, wrapped around a black lamp (TLD 18W/08) that emits radiation from 300 to $400 \mathrm{~nm}$; fluorescence detection: Ex $322 \mathrm{~nm}$; Em $380 \mathrm{~nm}$.

\subsubsection{Determination of vitamin $B_{6}$ through the vitamers pyridoxol, pyridoxal and} pyridoxamine

The analysis method was based on procedure described by Moreschi (2006), Presoto and Almeida-Muradian (2008), Kall (2003) and Arruda (2009). For the separation, $20 \mu \mathrm{L}$ were injected into column $\mathrm{C}_{18}$ reversed-phase Superspher $100 \mathrm{RP}-18$ endcapped $5 \mu \mathrm{m} / 250 \times 4.0 \mathrm{~mm}$ with pre-column $5 \mu \mathrm{m} / 4 \times 4 \mathrm{~mm}$ Lichrospher 100 $\mathrm{RP}-18$. The mobile phase was composed of phosphate buffer $\mathrm{pH} 2.5\left(0.68 \% \mathrm{KH}_{2} \mathrm{PO}_{4}\right)$ with ion pair ( $0.014 \%$ PIC 7) and acetonitrile (96:4); flow $0.6 \mathrm{~mL} / \mathrm{min}$; detection by fluorescence: Ex 296 nm; Em $390 \mathrm{~nm}$.

\subsubsection{Statistical analysis}

All the experiments were performed in triplicate $(n=3)$ and the results were expressed as mean \pm standard deviation. The studies were conducted in a fully randomized manner and all the obtained data were tested regarding normal distribution (Shapiro-Wilk test) and homogeneity of variances (Levene and Brown-Forsythe tests).

Upon finding that the conditions were met for the application of parametric statistical tests of mean comparison, the following statistical analysis were performed: comparison of vitamin content $\left(\mathrm{B}_{1}, \mathrm{~B}_{2}\right.$, PP e $\left.\mathrm{B}_{6}\right)$ in relation to each of the variables under study properly determined: time ( $0,4,8$ and 12 months) and storage conditions (light, dark and freezer); these were performed by the One-dimensional Variance Analysis (One-way ANOVA) followed by Tukey test.

The comparison of vitamin contents $\left(B_{1}, B_{2}, P P\right.$ and $\left.B_{6}\right)$ regarding the processing forms (fresh and dry), were carried out by Student's $t$ test for independent samples.

The analysis of the existence of a relation that could be mathematically described between the contents of vitamins $B_{1}, B_{2}, P P$ and $B_{6}$ and the storage periods $(0,4,8$ and 12 months) was performed by the use of linear Regression, using the coefficient of determination $\left(r^{2}\right)$ to assess the percentage of explicability of a variable in relation to the other ( $0-1$, with 1 representing $100 \%$ explicability).

In the sets of data in which the normal distributions and, specially, the homogeneity of variances were not observed, non-parametric statistical tests were employed. All statistical analysis were performed using the program STATISTICA 8.0 and adopting the significance level of $5 \%(p<0.05)$.

\section{Results and discussion}

\subsection{Analysis of fresh and dry bee pollen}

In the seven batches of analyzed bee pollen, all $\mathrm{B}$ vitamins proposed herein were identified - vitamin $B_{1}$ (thiamine), vitamin $B_{2}$ (riboflavin), three vitamers of $B_{6}$ vitamin (pyridoxol, pyridoxal and pyridoxamine) and two vitamers of PP vitamin (nicotinic acid and nicotinamide. The results of the concentrations of vitamins $B_{1}, B_{2}$ and $\mathrm{PP}$ in the samples of fresh and dried bee pollen are shown on Tables 1 and 2 . In order to exclude the effect of water quantity (moisture) of the samples in the quantification of vitamins, the estimated values were expressed on a dry basis (per $100 \mathrm{~g}$ of dry matter).

Concentrations of $\mathrm{B}_{1}$ vitamins varied between $0.59 \pm 0.05$ and $1.09 \pm 0.02 \mathrm{mg} / 100 \mathrm{~g}$ in the fresh samples and between $0.64 \pm 0.01$ and $1.01 \pm 0.01 \mathrm{mg} / 100 \mathrm{~g}$ in the dry samples. For vitamin $B_{2}$ the concentrations were between $1.73 \pm 0.04$ and $2.23 \pm 0.07 \mathrm{mg} / 100 \mathrm{~g}$ in the fresh samples and between $1.77 \pm 0.06$ and $2.56 \pm 0.05$ $\mathrm{mg} / 100 \mathrm{~g}$ in the dry samples (Table 1 ).

According to Ordinance No. 31, dated January 13, 1998 (Brasil, 2001), in terms of labeling, a solid food shall be considered source of a determined vitamin or mineral if it supplies $15 \%$ of the recommended daily intake (DRI) in the specified portion of the product. According to the DRI (IDR, 2005), $\mathrm{B}_{1}$ vitamin consumption 
Table 1

Concentrations of vitamins $\mathrm{B}_{1}, \mathrm{~B}_{2}$ and PP (including their vitamers) in the samples of fresh and dry bee pollen.

\begin{tabular}{|c|c|c|c|c|c|c|c|c|c|c|}
\hline \multirow[t]{3}{*}{ Batches } & \multicolumn{2}{|c|}{$\underline{\text { Vitamin }}_{B_{1}(\mathrm{mg} / 100 \mathrm{~g})^{*}}$} & \multicolumn{2}{|c|}{ Vitamin $B_{2}(\mathrm{mg} / 100 \mathrm{~g})^{*}$} & \multicolumn{6}{|c|}{$\underline{\text { Vitamin PP }(\mathrm{mg} / 100 \mathrm{~g})^{*}}$} \\
\hline & \multirow[t]{2}{*}{ Fresh } & \multirow[t]{2}{*}{ Dry } & \multirow[t]{2}{*}{ Fresh } & \multirow[t]{2}{*}{ Dry } & \multicolumn{3}{|l|}{ Fresh } & \multicolumn{3}{|l|}{ Dry } \\
\hline & & & & & Nicotinic Acid & Nicotinamide & Niacin & Nicotinic Acid & Nicotinamide & Niacin \\
\hline G & $1.09 \pm 0.02$ & $1.01 \pm 0.01$ & $2.41 \pm 0.22$ & $2.49 \pm 0.03$ & $4.44 \pm 0.14$ & $7.98 \pm 1.52$ & $15.34 \pm 1.69$ & $2.93 \pm 0.19$ & $10.42 \pm 0.44$ & $13.38 \pm 0.63$ \\
\hline $\mathrm{H}$ & $0.70 \pm 0.02$ & $0.68 \pm 0.03$ & $2.09 \pm 0.07$ & $1.92 \pm 0.03$ & $4.41 \pm 0.07$ & $8.72 \pm 1.81$ & $13.13 \pm 1.74$ & $3.22 \pm 0.17$ & $10.74 \pm 0.43$ & $13.96 \pm 0.26$ \\
\hline $\mathrm{I}$ & $0.60 \pm 0.04$ & $0.64 \pm 0.01$ & $2.23 \pm 0.07$ & $2.56 \pm 0.05$ & $2.94 \pm 0.02$ & $10.59 \pm 0.40$ & $13.54 \pm 0.43$ & $3.57 \pm 0.23$ & $9.83 \pm 0.21$ & $13.40 \pm 0.44$ \\
\hline $\mathrm{J}$ & $0.72 \pm 0.05$ & $0.74 \pm 0.06$ & $2.19 \pm 0.09$ & $2.05 \pm 0.04$ & $4.61 \pm 0.04$ & $8.80 \pm 1.86$ & $13.40 \pm 1.90$ & $3.72 \pm 0.13$ & $10.72 \pm 1.35$ & $14.43 \pm 1.21$ \\
\hline $\mathrm{K}$ & $0.60 \pm 0.05$ & $0.65 \pm 0.01$ & $1.73 \pm 0.04$ & $1.77 \pm 0.06$ & $3.04 \pm 0.02$ & $8.57 \pm 0.30$ & $11.61 \pm 0.29$ & $3.36 \pm 0.67$ & $10.58 \pm 0.05$ & $13.94 \pm 0.72$ \\
\hline $\mathrm{L}$ & $0.59 \pm 0.05$ & $0.66 \pm 0.01$ & $1.74 \pm 0.03$ & $1.79 \pm 0.02$ & $3.74 \pm 0.10$ & $2.69 \pm 0.25$ & $6.43 \pm 0.15$ & $2.03 \pm 0.09$ & $5.24 \pm 0.04$ & $7.27 \pm 0.15$ \\
\hline M & $0.77 \pm 0.03$ & $0.80 \pm 0.03$ & $1.96 \pm 0.02$ & $2.03 \pm 0.05$ & $2.42 \pm 0.43$ & $4.37 \pm 0.22$ & $6.79 \pm 0.66$ & $2.19 \pm 0.04$ & $6.72 \pm 0.37$ & $8.90 \pm 0.41$ \\
\hline Mean & $0.74 \pm 0.13$ & $0.64 \pm 0.11$ & $0.69 \pm 0.08$ & $0.60 \pm 0.11$ & $3.66 \pm 0.87$ & $7.39 \pm 2.80$ & $11.46 \pm 3.49$ & $3.00 \pm 0.66$ & $9.18 \pm 2.25$ & $12.18 \pm 2.86$ \\
\hline
\end{tabular}

Table 2

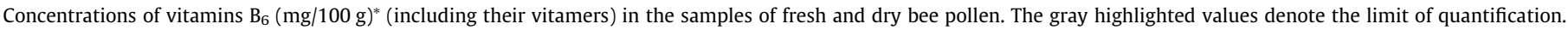

\begin{tabular}{|c|c|c|c|c|c|c|c|c|}
\hline \multirow[t]{2}{*}{ Batches } & \multicolumn{4}{|l|}{ Fresh } & \multicolumn{4}{|l|}{ Dry } \\
\hline & Pyridoxol & Pyridoxal & Pyridoxamine & Vitamin $\mathrm{B}_{6}$ & Pyridoxol & Pyridoxal & Pyridoxamine & Vitamin $\mathrm{B}_{6}$ \\
\hline G & $0.06 \pm 0.01$ & $0.18 \pm 0.01$ & $0.43 \pm 0.01$ & $0.61 \pm 0.02$ & $0.09 \pm 0.01$ & $0.20 \pm 0.03$ & $0.36 \pm 0.02$ & $0.65 \pm 0.00$ \\
\hline $\mathrm{H}$ & $0.04 \pm 0.00$ & $0.08 \pm 0.01$ & $0.42 \pm 0.00$ & $0.50 \pm 0.00$ & $0.05 \pm 0.00$ & $0.08 \pm 0.00$ & $0.25 \pm 0.01$ & $0.33 \pm 0.01$ \\
\hline I & $0.05 \pm 0.00$ & $0.10 \pm 0.01$ & $0.042 \pm 0.00$ & $0.52 \pm 0.01$ & $0.04 \pm 0.00$ & $0.12 \pm 0.00$ & $0.28 \pm 0.01$ & $0.40 \pm 0.01$ \\
\hline $\mathrm{J}$ & $0.07 \pm 0.01$ & $0.22 \pm 0.09$ & $0.42 \pm 0.01$ & $0.71 \pm 0.09$ & $0.06 \pm 0.00$ & $0.18 \pm 0.02$ & $0.26 \pm 0.02$ & $0.44 \pm 0.01$ \\
\hline $\mathrm{K}$ & $0.11 \pm 0.01$ & $0.019 \pm 0.01$ & $0.50 \pm 0.02$ & $0.79 \pm 0.03$ & $0.09 \pm 0.00$ & $0.31 \pm 0.05$ & $0.37 \pm 0.00$ & $0.77 \pm 0.06$ \\
\hline $\mathrm{L}$ & $0.09 \pm 0.00$ & $0.17 \pm 0.02$ & $0.45 \pm 0.01$ & $0.71 \pm 0.01$ & $0.09 \pm 0.01$ & $0.11 \pm 0.01$ & $0.37 \pm 0.02$ & $0.57 \pm 0.04$ \\
\hline M & $0.06 \pm 0.01$ & $0.11 \pm 0.01$ & $0.54 \pm 0.03$ & $0.65 \pm 0.04$ & $0.07 \pm 0.00$ & $0.14 \pm 0.00$ & $0.49 \pm 0.08$ & $0.71 \pm 0.08$ \\
\hline Mean & $0.09 \pm 0.02$ & $0.15 \pm 0.05$ & $0.45 \pm 0.05$ & $0.64 \pm 0.11$ & $0.08 \pm 0.01$ & $0.16 \pm 0.08$ & $0.34 \pm 0.08$ & $0.55 \pm 0.17$ \\
\hline
\end{tabular}

should be $1.2 \mathrm{mg} /$ day for adults. Fifteen percentage of this value represents $0.18 \mathrm{mg}$ of $\mathrm{B}_{1}$ vitamin for adults. In the case of $\mathrm{B}_{2}$ vitamin, the DRI is $1.3 \mathrm{mg} /$ day for adults and $15 \%$ of this amount is equivalent to the intake of 0.20 of $\mathrm{B}_{2}$ vitamin in the portion. As the recommended daily intake portion for dry bee pollen is up to $25 \mathrm{~g}$, we verified that the three analyzed batches ( $\mathrm{G}$, J and $\mathrm{M}$ ) could be considered vitamin $B_{1}$ source, providing at least $15 \%$ of the Recommended Daily Intake (RDI). In the case of vitamin $B_{2}$, all batches were sources since they contained amounts higher than $32 \%$ of the Recommended Daily Intake (RDI) and the average amount of the concentrations provided approximately $40 \%$ of the Recommended Daily Intake (RDI).

The concentration of vitamin PP, shown on Table 1, considering its two vitamers, varied between $6.43 \pm 0.15$ and $15.34 \pm 1.69$ $\mathrm{mg} / 100 \mathrm{~g}$ in the fresh samples and between $7.27 \pm 0.15$ and $14.43 \pm 1.21 \mathrm{mg} / 100 \mathrm{~g}$ in the dry samples.

The recommended daily intake of vitamin PP is $16 \mathrm{mg} /$ day for adults (DRI, 2005) and 15\% of this amount represents $2.4 \mathrm{mg}$ of vitamin PP in the portion. Therefore, in terms of labeling, five analyzed batches $(\mathrm{G}-\mathrm{K})$ could be considered source for this vitamin, providing at least $20 \%$ of the RDI.

The concentration of vitamin $\mathrm{B}_{6}$ shown on Table 2 , varied between $0.50 \pm 0.00$ and $0.79 \pm 0.03 \mathrm{mg} / 100 \mathrm{~g}$ in the fresh samples and between $0.33 \pm 0.01$ and $0.77 \pm 0.06 \mathrm{mg} / 100 \mathrm{~g}$ in the dry samples. For vitamin $B_{6}$, the RDI is $1.3 \mathrm{mg} /$ day for adults and $15 \%$ of this value would represent the intake of $0.20 \mathrm{mg}$ of vitamin per portion. According to the results, the bee pollen would provide 0.10 to $0.19 \mathrm{mg}$ of vitamin in its daily portion; therefore, in terms of labeling, it could not be considered a source of vitamin $B_{6}$.

Although some authors state that the chemical composition of pollen can vary depending on the plant species, environmental conditions, age, nutritional status of the plant when the pollen is developing in different locations or developing between seasons and different years (Barreto et al., 2006; Morais et al., 2011), the samples analyzed in this work presented concentrations of B complex vitamins in agreement with the studies carried out by
Stanley and Linskens (1974). Szczesna and Rybak-Chmielewska (1998) and Campos et al. (2008) reported values of $6-13 \mathrm{mg} / \mathrm{kg}$; $6-20 \mathrm{mg} / \mathrm{kg} ; 40-110 \mathrm{mg} / \mathrm{kg}$ and $2-7 \mathrm{mg} / \mathrm{kg}$ for thiamine, riboflavin, niacin and pyridoxine respectively. Sánchez (2004) reported the amount $5 \mu \mathrm{g} / \mathrm{g}$ of vitamin $\mathrm{B}_{6}$ in bee pollen while Donadieu (1983) presented intervals from 16.30 to $19.20 \mu \mathrm{g} / \mathrm{g}$ for vitamin $\mathrm{B}_{2}$ and $0-9 \mu \mathrm{g} / \mathrm{g}$ (on a dry basis) for vitamin $\mathrm{B}_{6}$. There are not any studies in Brazil or Portugal reporting the content of B complex vitamins in bee pollen, what justifies the pertinence of this work.

The amounts of the vitamer Pyridoxol found in the samples were very low, sometimes below the limit of quantification $(0.07$ $\mathrm{mg} / 100 \mathrm{~g}$ ) both in fresh samples (batches $\mathrm{G}, \mathrm{H}, \mathrm{I}$ and $\mathrm{M}$ ) and dry samples (batches $\mathrm{H}-\mathrm{J}$ ). The concentrations found for the other vitamers (Pyridoxal and Pyridoxamine) were always above that limit.

The literature describes that one of the most important steps in the production of bee pollen is the drying process, which is responsible for promoting the preservation and for increasing the shelf life of the product (Moreira et al., 2008). In the present work, as shown in Tables 1 and 2, it can be observed that the drying process did not interfere in the concentrations of any vitamin in question, in the bee pollen matrix $(p<0.05)$. Therefore, besides favoring the commercialization of the product since it increases the expiry date, the drying process did not interfere in the nutritional values. In the work published by Melo and Almeida-Muradian (2010), the drying process was responsible for the decrease in $67.1 \%$ of vitamin $C$ concentration, $18.7 \%$ for vitamin $\mathrm{E}$ and $15.6 \%$ for $\beta$-carotene.

\subsection{Analysis of dry bee pollen after storage}

The seven batches of analyzed dry bee pollen were stored in three different conditions: (i) at room temperature with exposure to light; (ii) at room temperature protected from light and (iii) in freezer. The samples were stored in transparent plastic packages and labeled as sent by the commercial warehouse. The results obtained in the analysis of vitamins $\mathrm{B}_{1}$ (thiamine), $\mathrm{B}_{2}$ (riboflavin) and vitamin PP 
Table 3

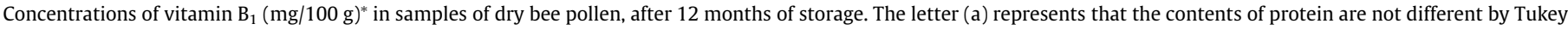
test with significance of $\alpha=0.05$.

\begin{tabular}{|c|c|c|c|c|c|c|c|c|c|c|}
\hline \multirow[t]{3}{*}{ Batches } & \multirow[t]{3}{*}{ Time 0} & \multicolumn{9}{|l|}{ Condition } \\
\hline & & \multicolumn{3}{|l|}{ Light } & \multicolumn{3}{|l|}{ Dark } & \multicolumn{3}{|l|}{ Freezer } \\
\hline & & 4 months & 8 months & 12 months & 4 months & 8 months & 12 months & 4 months & 8 months & 12 months \\
\hline G & $1.01 \pm 0.01$ & $0.84 \pm 0.01$ & $0.82 \pm 0.06$ & $0.83 \pm 0.04$ & $0.89 \pm 0.03$ & $0.83 \pm 0.03$ & $0.85 \pm 0.03$ & $0.96 \pm 0.03$ & $0.91 \pm 0.00$ & $0.94 \pm 0.04$ \\
\hline $\mathrm{H}$ & $0.68 \pm 0.03$ & $0.61 \pm 0.01$ & $0.67 \pm 0.02$ & $0.65 \pm 0.09$ & $0.62 \pm 0.02$ & $0.71 \pm 0.02$ & $0.62 \pm 0.05$ & $0.67 \pm 0.02$ & $0.76 \pm 0.04$ & $0.67 \pm 0.04$ \\
\hline I & $0.64 \pm 0.01$ & $0.56 \pm 0.01$ & $0.69 \pm 0.02$ & $0.56 \pm 0.02$ & $0.60 \pm 0.02$ & $0.72 \pm 0.07$ & $0.61 \pm 0.01$ & $0.64 \pm 0.01$ & $0.79 \pm 0.00$ & $0.64 \pm 0.04$ \\
\hline $\mathrm{J}$ & $0.74 \pm 0.06$ & $0.63 \pm 0.03$ & $0.61 \pm 0.01$ & $0.55 \pm 0.04$ & $0.64 \pm 0.00$ & $0.63 \pm 0.00$ & $0.55 \pm 0.04$ & $0.72 \pm 0.02$ & $0.71 \pm 0.03$ & $0.58 \pm 0.01$ \\
\hline $\mathrm{K}$ & $0.65 \pm 0.01$ & $0.54 \pm 0.04$ & $0.62 \pm 0.01$ & $0.51 \pm 0.01$ & $0.60 \pm 0.03$ & $0.66 \pm 0.02$ & $0.55 \pm 0.06$ & $0.65 \pm 0.02$ & $0.78 \pm 0.10$ & $0.65 \pm 0.07$ \\
\hline $\mathrm{L}$ & $0.66 \pm 0.01$ & $0.59 \pm 0.02$ & $0.66 \pm 0.01$ & $0.53 \pm 0.03$ & $0.63 \pm 0.09$ & $0.62 \pm 0.02$ & $0.54 \pm 0.02$ & $0.65 \pm 0.01$ & $0.68 \pm 0.03$ & $0.56 \pm 0.06$ \\
\hline M & $0.80 \pm 0.03$ & $0.72 \pm 0.01$ & $0.76 \pm 0.01$ & $0.60 \pm 0.05$ & $0.73 \pm 0.03$ & $0.64 \pm 0.03$ & $0.73 \pm 0.05$ & $0.80 \pm 0.02$ & $0.86 \pm 0.01$ & $0.79 \pm 0.01$ \\
\hline Mean & $0.74 \pm 0.13$ & $0.64 \pm 0.11$ & $0.69 \pm 0.08$ & $0.60 \pm 0.11$ & $0.67 \pm 0.11$ & $0.69 \pm 0.07$ & $0.64 \pm 0.12$ & $0.73 \pm 0.16$ & $0.78 \pm 0.08$ & $0.69 \pm 0.13$ \\
\hline
\end{tabular}

Table 4

Concentrations of vitamin $B_{2}(\mathrm{mg} / 100 \mathrm{~g})^{*}$ in samples of dry bee pollen, after 12 months of storage.

\begin{tabular}{|c|c|c|c|c|c|c|c|c|c|c|}
\hline \multirow[t]{3}{*}{ Batches } & \multirow[t]{3}{*}{ Time 0} & \multicolumn{9}{|l|}{ Condition } \\
\hline & & \multicolumn{3}{|l|}{ Light } & \multicolumn{3}{|l|}{ Dark } & \multicolumn{3}{|l|}{ Freezer } \\
\hline & & 4 months & 8 months & 12 months & 4 months & 8 months & 12 months & 4 months & 8 months & 12 months \\
\hline G & $2.49 \pm 0.03$ & $1.15 \pm 0.02$ & $1.76 \pm 0.07$ & $1.81 \pm 0.03$ & $1.41 \pm 0.05$ & $1.93 \pm 0.10$ & $1.51 \pm 0.02$ & $1.48 \pm 0.03$ & $2.05 \pm 0.05$ & $1.37 \pm 0.02$ \\
\hline $\mathrm{H}$ & $1.92 \pm 0.03$ & $1.45 \pm 0.06$ & $1.32 \pm 0.07$ & $1.37 \pm 0.03$ & $1.57 \pm 0.03$ & $1.39 \pm 0.09$ & $1.56 \pm 0.03$ & $1.61 \pm 0.02$ & $1.54 \pm 0.05$ & $1.62 \pm 0.04$ \\
\hline I & $2.56 \pm 0.05$ & $1.46 \pm 0.07$ & $1.27 \pm 0.01$ & $1.14 \pm 0.01$ & $1.55 \pm 0.01$ & $1.35 \pm 0.05$ & $1.25 \pm 0.03$ & $1.64 \pm 0.06$ & $1.47 \pm 0.01$ & $1.27 \pm 0.01$ \\
\hline $\mathrm{J}$ & $2.05 \pm 0.04$ & $1.32 \pm 0.06$ & $1.36 \pm 0.02$ & $1.29 \pm 0.03$ & $1.46 \pm 0.02$ & $1.52 \pm 0.01$ & $1.42 \pm 0.05$ & $1.52 \pm 0.03$ & $1.57 \pm 0.03$ & $1.43 \pm 0.03$ \\
\hline $\mathrm{K}$ & $1.77 \pm 0.06$ & $1.44 \pm 0.02$ & $1.03 \pm 0.05$ & $1.47 \pm 0.04$ & $1.54 \pm 0.02$ & $1.15 \pm 0.01$ & $1.58 \pm 0.03$ & $1.55 \pm 0.00$ & $1.30 \pm 0.05$ & $1.59 \pm 0.05$ \\
\hline $\mathrm{L}$ & $1.79 \pm 0.02$ & $1.07 \pm 0.04$ & $1.34 \pm 0.13$ & $1.62 \pm 0.05$ & $1.18 \pm 0.05$ & $1.55 \pm 0.11$ & $1.65 \pm 0.07$ & $1.27 \pm 0.01$ & $1.43 \pm 0.13$ & $1.72 \pm 0.03$ \\
\hline M & $2.03 \pm 0.05$ & $1.25 \pm 0.01$ & $1.67 \pm 0.11$ & $1.77 \pm 0.07$ & $1.38 \pm 0.03$ & $1.60 \pm 0.04$ & $1.96 \pm 0.04$ & $1.42 \pm 0.09$ & $1.68 \pm 0.06$ & $2.01 \pm 0.03$ \\
\hline Mean & $2.09 \pm 0.32$ & $1.31 \pm 0.16^{\mathrm{a}}$ & $1.39 \pm 0.25^{\mathrm{a}}$ & $1.50 \pm 0.25^{\mathrm{a}}$ & $1.44 \pm 0.14^{\mathrm{a}}$ & $1.50 \pm 0.24^{\mathrm{a}}$ & $1.56 \pm 0.22^{\mathrm{a}}$ & $1.50 \pm 0.13^{\mathrm{a}, \mathrm{b}}$ & $1.58 \pm 0.24^{\mathrm{a}}$ & $1.54 \pm 0.25^{\mathrm{a}}$ \\
\hline
\end{tabular}

${ }^{a}$ Differences statistically significant in relation to time 0 of each storage condition $(p<0.05)$.

b Differences statistically significant in relation to storage in light $(p<0.05)$

Table 5

Concentrations of vitamin PP (mg/100 g)* in samples of dry bee pollen, after 12 months of storage.

\begin{tabular}{|c|c|c|c|c|c|c|c|c|c|c|}
\hline \multirow[t]{3}{*}{ Batches } & \multirow[t]{3}{*}{ Time 0} & \multicolumn{9}{|l|}{ Condition } \\
\hline & & \multicolumn{3}{|l|}{ Light } & \multicolumn{3}{|l|}{ Dark } & \multicolumn{3}{|l|}{ Freezer } \\
\hline & & 4 months & 8 months & 12 months & 4 months & 8 months & 12 months & 4 months & 8 months & 12 months \\
\hline G & $13.38 \pm 0.63$ & $9.31 \pm 0.91$ & $7.93 \pm 0.90$ & $2.74 \pm 0.22$ & $9.49 \pm 0.09$ & $7.98 \pm 0.21$ & $3.33 \pm 0.06$ & $8.19 \pm 0.70$ & $7.63 \pm 0.41$ & $3.37 \pm 0.10$ \\
\hline $\mathrm{H}$ & $13.96 \pm 0.26$ & $6.93 \pm 0.92$ & $7.78 \pm 0.24$ & $3.52 \pm 0.15$ & $7.99 \pm 0.39$ & $7.56 \pm 0.26$ & $3.74 \pm 0.51$ & $7.73 \pm 0.34$ & $6.72 \pm 0.26$ & $4.82 \pm 0.84$ \\
\hline I & $13.40 \pm 0.44$ & $7.53 \pm 0.08$ & $7.09 \pm 0.04$ & $5.32 \pm 0.09$ & $7.29 \pm 0.15$ & $7.49 \pm 0.24$ & $5.25 \pm 0.18$ & $6.89 \pm 0.34$ & $6.31 \pm 0.18$ & $5.29 \pm 0.40$ \\
\hline $\mathrm{J}$ & $14.43 \pm 1.21$ & $5.55 \pm 0.10$ & $7.54 \pm 0.14$ & $5.31 \pm 0.16$ & $5.56 \pm 0.12$ & $7.32 \pm 0.26$ & $5.28 \pm 0.11$ & $5.60 \pm 0.24$ & $6.93 \pm 0.40$ & $4.79 \pm 0.19$ \\
\hline $\mathrm{K}$ & $13.94 \pm 0.72$ & $6.27 \pm 0.25$ & $4.48 \pm 0.80$ & $4.82 \pm 0.37$ & $5.78 \pm 0.06$ & $5.58 \pm 0.21$ & $4.91 \pm 0.20$ & $5.48 \pm 0.26$ & $4.89 \pm 0.72$ & $4.36 \pm 0.18$ \\
\hline $\mathrm{L}$ & $7.27 \pm 0.15$ & $5.54 \pm 0.58$ & $6.68 \pm 0.12$ & $5.21 \pm 0.40$ & $5.23 \pm 0.15$ & $6.01 \pm 0.34$ & $5.37 \pm 0.17$ & $5.09 \pm 0.03$ & $6.51 \pm 0.82$ & $4.67 \pm 0.15$ \\
\hline M & $8.9 \pm 0.41$ & $5.42 \pm 0.29$ & $7.96 \pm 0.23$ & $5.06 \pm 0.18$ & $5.12 \pm 0.31$ & $6.93 \pm 0.30$ & $3.83 \pm 0.90$ & $5.04 \pm 0.06$ & $5.87 \pm 0.18$ & $4.55 \pm 0.02$ \\
\hline Mean & $12.18 \pm 2.86$ & $6.65 \pm 1.42$ & $7.07 \pm 1.23$ & $4.57 \pm 1.02^{\mathrm{a}}$ & $6.64 \pm 1.66$ & $6.98 \pm 0.88$ & $4.53 \pm 0.86^{a}$ & $6.29 \pm 1.30$ & $6.41 \pm 0.86$ & $4.55 \pm 0.59^{\mathrm{a}}$ \\
\hline
\end{tabular}

a Statistical significant differences when compared with the initial time for each storage condition $(p<0.05)$.

(niacin and niacinamide), after 0, 4, 8 and 12 months of storage are shown in Tables 3-5 and Fig 1. In Table 6 we can see the concentrations of vitamin $B_{6}$ (including its vitamers pyridoxol, pyridoxal and pyridoxamine) in samples of dried bee pollen with $0,4,8$ and 12 months of storage at room temperature (with and without light) and freezer.

Through the results obtained in the study of stability, we verified that the vitamin $B_{1}$ in the matrix bee pollen remained stable during the proposed period of study in the three storage conditions (Table 3 ). Only after 8 months, the storage in freezer resulted in losses marginally lower $(p<0.10)$ of vitamin $\mathrm{B}_{1}$, when compared to the other storage conditions.

For vitamin $B_{2}$ a significant loss from time 0 to times 4,8 and 12 months was observed $(p<0.05)$, with amounts of loss similar to the three storage conditions (Table 4 ), except for the result of 4 months, in which the storage in freezer resulted in lower losses of vitamin than storage at light $(p<0.05)$, remaining stable until the end of the study.
After 12 months of storage, it was verified that all batches in the three storage conditions could still be considered as source of vitamin $B_{2}$, providing amounts that varied between $21.9 \%$ and $38.75 \%$ of the Recommended Daily Intake (RDI).

For vitamin PP (niacin and niacinamide), a significant decrease was observed from time 0 to time 12 months $(p<0.05)$ of $60 \%$ for all conditions and marginally significant differences from 0 to the 4 th month and from the 8th to the 12th months $(p<0.10)$, as shown in Table 5.

After 4 months of storage, the five batches $(\mathrm{G}-\mathrm{K})$, previously considered a source of vitamin PP, are at concentrations below 9.6 $\mathrm{mg} / 100 \mathrm{~g}$, amount required to be considered source of this vitamin.

In the case of vitamin $B_{6}$, a significant decrease of concentration was observed from time 0 to times 8 and 12 months ( $p<0.05$ ), when the vitamin was not detected in any of the sample batches and under any of the proposed storage conditions, as shown in Table 6 .

It was also observed that the concentrations of vitamers Pyridoxol and Pyridoxal were below the quantification limits 
Vitamin $\mathbf{B}_{1}$

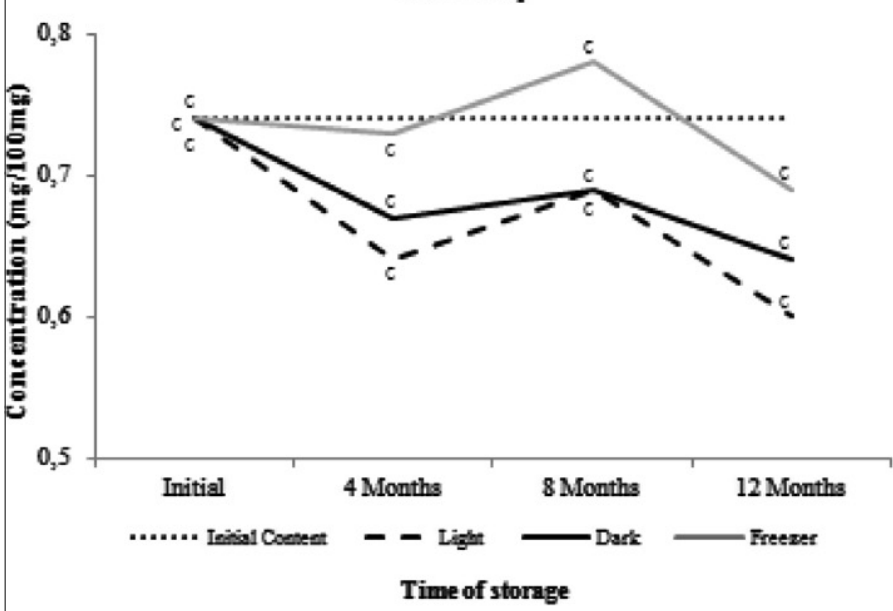

Vitamin PP

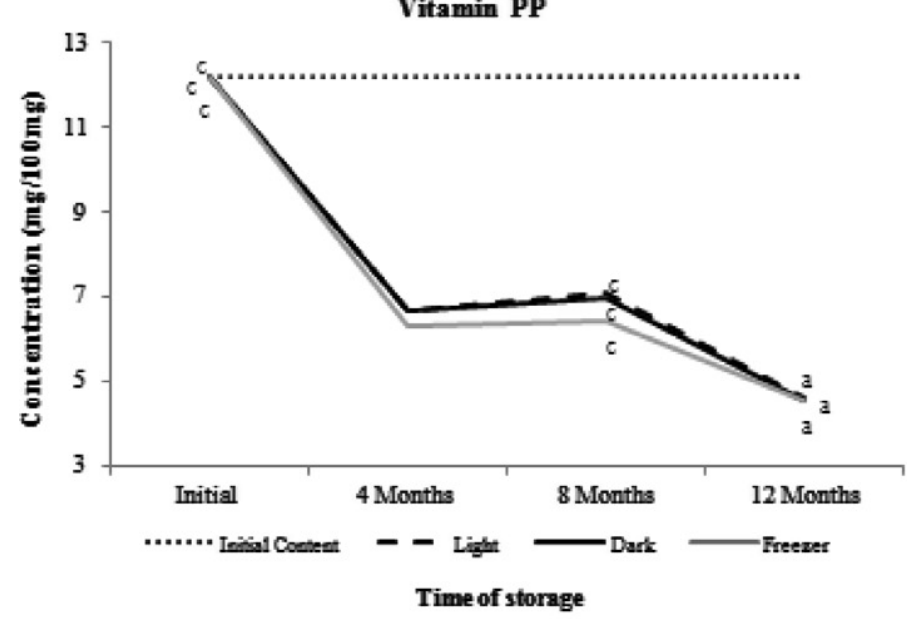

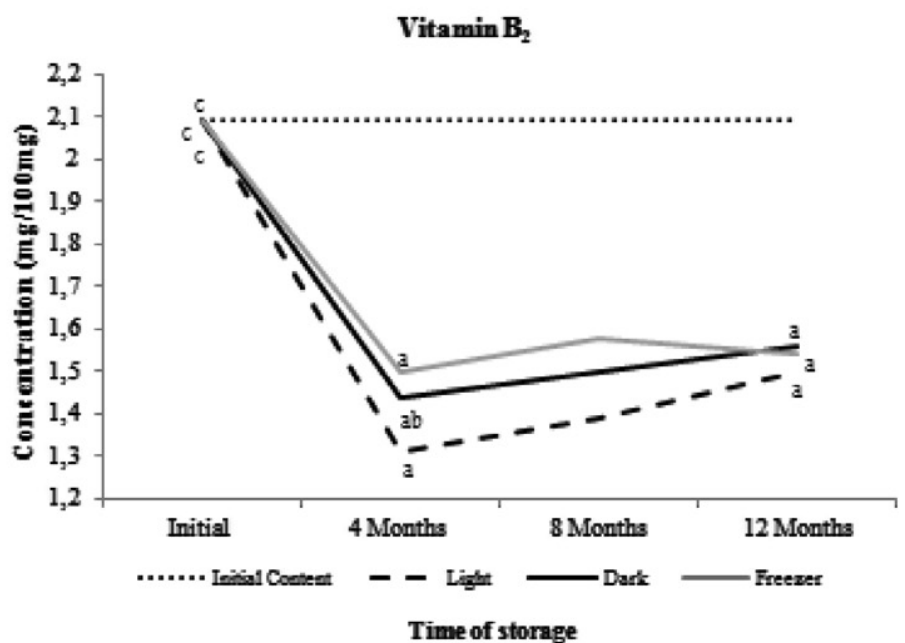

Vitamin $\mathbf{B}_{6}$

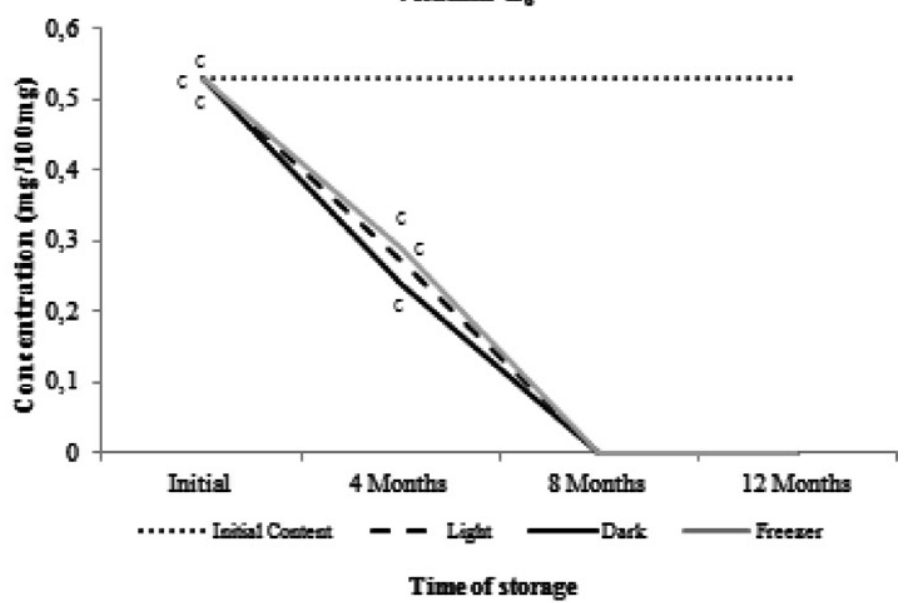

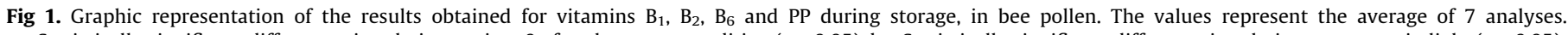

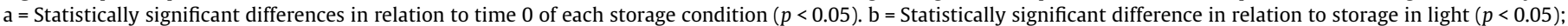
$c=$ Represents that the concentration of vitamins are not different by Tukey test with significance of $\alpha=0.05$.

calculated during the validation stage of the method, 0.07 and $0.04 \mathrm{mg} / 100 \mathrm{~g}$, respectively.

Although cold and dark environments are considered ideal for storing bee pollen in order to preserve its nutritional value (Campos et al., 2003), it was verified in the present work that to store in freezer $\left(-18^{\circ} \mathrm{C}\right)$ or protected from the effects of light had no positive effect on the concentrations of the vitamins studied. However, in the work of Melo and Almeida-Muradian (2010), who studied the effect of the same storage conditions on the content of antioxidant vitamins ( $\mathrm{A}, \mathrm{E}$ and $\beta$-carotene), the storage in freezer was more effective for the preservation of vitamins. In the present work, the results were dependent on storage time and not on the condition in which the sample was maintained. This suggests that there is no need to develop packages that protect from light; also, there is no need to store the product in the freezer to preserve the B complex vitamins. These procedures would incur in higher investments by the industry and sellers of bee pollen.

The content of pollen nutrients can also change with the storage. Szczesna and Rybak-Chmielewska (1998) estimated the effect of different preservation methods (freezing, drying at approximately $40{ }^{\circ} \mathrm{C}$ and freeze drying) on the selected parameters assigned to the biological quality of the bee pollen. Freezing did not cause any substantial change in the chemical composition of the pollen, so this technique can be recommended when the preservation of the pollen load for food or for therapeutic purposes is important.

Another very interesting fact is that it was mathematically possible to explain the influence of storage time on the concentrations of vitamins $B_{6}$ and PP, for all storage conditions simultaneously, through the establishment of linear regression equations. In fact, Azanha \& Faria (2005) claimed that the product quality is often mathematically modeled around a parameter (concentration of a chemical compound, a microbiological index, or moisture content).

The decrease in concentrations of vitamins $B_{6}$ can be explained at $76 \%$ level due to the increase of storage time $\left(r^{2}=0.76\right)$, according to the following equation: $\left[\mathrm{B}_{6}\right]=0.48-0.047 \times$ storage time, while for vitamin PP the explicability level was $60 \%$ due to the increase in storage time $\left(r^{2}=0.60\right)$, according to the following equation: $[\mathrm{PP}]=10.97-0.56 \times$ storage time.

It is noteworthy that after external validation, these equations could be applied to predict vitamin content of pollens in general, at least within the studied storage range (0-12 months). Further studies about the mode of deterioration of the product are fundamental to understanding and setting up the limits to confirm the described models. 
Table 6

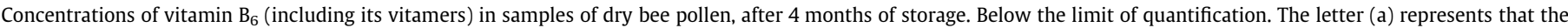
contents of protein are not different by Tukey test with significance of $\alpha=0.05$.

\begin{tabular}{|c|c|c|c|c|c|c|c|c|c|c|c|c|}
\hline \multicolumn{4}{|l|}{ Batches } & \multicolumn{9}{|l|}{ Condition } \\
\hline & \multicolumn{3}{|l|}{ Time 0} & \multicolumn{3}{|l|}{ Light } & \multicolumn{3}{|l|}{ Dark } & \multicolumn{3}{|l|}{ Freezer } \\
\hline & Pyridoxol & Pyridoxal & Pyridoxamine & Pyridoxol & Pyridoxal & Pyridoxamine & Pyridoxol & Pyridoxal & Pyridoxamine & Pyridoxol & Pyridoxal & Pyridoxamine \\
\hline G & $0.09 \pm 0.01$ & $0.20 \pm 0.03$ & $0.36 \pm 0.02$ & $0.06 \pm 0.00$ & $0.05 \pm 0.00$ & $0.18 \pm 0.00$ & $0.06 \pm 0.00$ & $0.04 \pm 0.00$ & $0.16 \pm 0.03$ & $0.08 \pm 0.00$ & $0.03 \pm 0.00$ & $0.24 \pm 0.05$ \\
\hline $\mathrm{H}$ & $0.05 \pm 0.00$ & $0.08 \pm 0.00$ & $0.25 \pm 0.01$ & $0.04 \pm 0.00$ & $0.04 \pm 0.00$ & $0.17 \pm 0.00$ & $0.04 \pm 0.00$ & $0.04 \pm 0.01$ & $0.17 \pm 0.02$ & $0.03 \pm 0.00$ & $0.04 \pm 0.01$ & $0.24 \pm 0.01$ \\
\hline I & $0.04 \pm 0.00$ & $0.12 \pm 0.00$ & $0.28 \pm 0.01$ & $0.04 \pm 0.01$ & $0.05 \pm 0.01$ & $0.21 \pm 0.00$ & $0.05 \pm 0.00$ & $0.03 \pm 0.00$ & $0.23 \pm 0.02$ & $0.04 \pm 0.01$ & $0.04 \pm 0.00$ & $0.29 \pm 0.01$ \\
\hline J & $0.06 \pm 0.00$ & $0.18 \pm 0.02$ & $0.26 \pm 0.02$ & $0.08 \pm 0.00$ & $0.03 \pm 0.01$ & $0.19 \pm 0.01$ & $0.04 \pm 0.00$ & $0.11 \pm 0.00$ & $0.20 \pm 0.00$ & $0.04 \pm 0.01$ & $0.10 \pm 0.01$ & $0.27 \pm 0.02$ \\
\hline $\mathrm{K}$ & $0.09 \pm 0.00$ & $0.31 \pm 0.05$ & $0.37 \pm 0.00$ & $0.04 \pm 0.00$ & $0.12 \pm 0.00$ & $0.24 \pm 0.00$ & $0.03 \pm 0.00$ & $0.12 \pm 0.00$ & $0.23 \pm 0.02$ & $0.04 \pm 0.00$ & $0.12 \pm 0.02$ & $0.32 \pm 0.03$ \\
\hline $\mathrm{L}$ & $0.09 \pm 0.01$ & $0.11 \pm 0.01$ & $0.37 \pm 0.02$ & $0.08 \pm 0.01$ & $0.04 \pm 0.00$ & $0.08 \pm 0.01$ & $0.08 \pm 0.01$ & $0.04 \pm 0.00$ & $0.08 \pm 0.04$ & $0.06 \pm 0.00$ & $0.04 \pm 0.00$ & $0.06 \pm 0.02$ \\
\hline M & $0.07 \pm 0.00$ & $0.14 \pm 0.00$ & $0.49 \pm 0.08$ & $0.06 \pm 0.01$ & $0.05 \pm 0.01$ & $0.08 \pm 0.01$ & $0.07 \pm 0.01$ & $0.05 \pm 0.00$ & $0.07 \pm 0.01$ & $0.07 \pm 0.01$ & $0.05 \pm 0.00$ & $0.09 \pm 0.00$ \\
\hline \multirow[t]{4}{*}{ Batches } & \multicolumn{12}{|c|}{ Vitamin $B_{6}(\mathrm{mg} / 100 \mathrm{~g}) *$} \\
\hline & Time 0 & & & Condition & & & & & & & & \\
\hline & & & & Light & & & Dark & & & Freezer & & \\
\hline & Vitamin $B_{6}$ & & & Vitamin $\mathrm{B}_{6}$ & & & Vitamin $B_{6}$ & & & Vitamin $\mathrm{B}_{6}$ & & \\
\hline G & $0.65 \pm 0.00$ & $0.23 \pm 0.00$ & $0.20 \pm 0.03$ & $0.35 \pm 0.05$ & & & & & & & & \\
\hline $\mathrm{H}$ & $0.33 \pm 0.01$ & $0.21 \pm 0.00$ & $0.21 \pm 0.01$ & $0.28 \pm 0.02$ & & & & & & & & \\
\hline I & $0.40 \pm 0.01$ & $0.26 \pm 0.01$ & $0.23 \pm 0.02$ & $0.31 \pm 0.02$ & & & & & & & & \\
\hline J & $0.44 \pm 0.01$ & $0.27 \pm 0.00$ & $0.31 \pm 0.00$ & $0.37 \pm 0.02$ & & & & & & & & \\
\hline $\mathrm{K}$ & $0.77 \pm 0.06$ & $0.36 \pm 0.00$ & $0.35 \pm 0.02$ & $0.44 \pm 0.00$ & & & & & & & & \\
\hline $\mathrm{L}$ & $0.57 \pm 0.04$ & $0.19 \pm 0.00$ & $0.20 \pm 0.05$ & $0.10 \pm 0.02$ & & & & & & & & \\
\hline M & $0.71 \pm 0.08$ & $0.13 \pm 0.03$ & $0.20 \pm 0.02$ & $0.21 \pm 0.01$ & & & & & & & & \\
\hline Mean & $0.53 \pm 0.17$ & $0.27 \pm 0.07$ & $0.24 \pm 0.06$ & $0.29 \pm 0.11$ & & & & & & & & \\
\hline
\end{tabular}

\section{Conclusions}

This study describes, for the first time, the presence and stability of B complex vitamins in bee pollen, depending on the storage conditions. Three batches were sources of $B_{1}$, all the samples were sources of vitamin $B_{2}, 5$ of the analyzed samples were sources of PP and none of them was source of $B_{6}$.

It can be concluded that the dehydration process, which is favorable for the preservation of the product and the increase of shelf life, did not interfere in the content of complex B vitamins $(p<0.05)$. In general, it can be stated that the concentration of vitamins was dependent on storage time and not on the conditions in which the dry pollen was stored $(p<0.05)$. It was possible to explain mathematically, through linear regression equations derived from multivariate analysis, the influence of storage time on the concentrations of vitamins $\mathrm{B}_{6}$ and $\mathrm{PP}$, explained as $76 \%$ and $60 \%$ respectively, for these samples and under these conditions.

Variations in the vitamins' concentrations can be due to the botanical origin, meteorological conditions, type of soil and handling. In this context, further studies with a larger number of bee pollen samples are necessary to confirm the findings.

\section{Conflict of Interest}

None declared.

\section{Acknowledgments}

The authors wish to thank the National Council for Scientific and Technological Development - CNPq; Sao Paulo Research Foundation - FAPESP for the scholarships and financial support, and to the company Pronatu Laboratório de Produtos Naturais Ltda. for providing the samples.

\section{References}

Almeida-Muradian, L.B., Pamplona, L.C., Coimbra, S., Barth, O.M., 2005. Chemical composition and botanical evaluation of dried bee pollen pellets. Journal of Food Composition and Analysis 18, 105-111.

Arruda, V.A.S., 2009. Estabilidade de vitaminas do Complexo B em pólen apícola. MS thesis, Faculdade de Ciências Farmacêuticas, Universidade de São Paulo, p. 110

Augustin, J., 1984. Simultaneous determination of thiamine and riboflavin in foods by liquid chromatography. Journal of Association of Official Analytical Chemists 67, 1012-1015
Barreto, L.M.R.C., Funari, S.R.C., Orsi, R.O., Dib, A.P.S., 2006. Produção de pólen no Brasil. Cabral Editora e Livraria Universitária, Taubaté.

Bogdanov, S., 2004. Quality and standards of pollen and beeswax. Apiacta 38, 334341.

Brasil, 2001. Ministério da Saúde. Agência Nacional de Vigilância Sanitária. Legislação. VisaLegis. Instrução Normativa n.3, de 19 de janeiro de 2001 . Aprova os Regulamentos Técnicos de Identidade e Qualidade de Apitoxina, Cera de Abelha, Geléia Real, Geléia Real Liofilizada, Pólen Apícola, Própolis e Extrato de Própolis. <http://www.e-legis.bvs.br/leisref/public/ showAct.php?id=12479\&word $>$ (accessed 05.11..2011.).

Campos, M.G., Webby, R.F., Mitchell, K.A., Markham, K.R., Cunha, A.P., 2003. Ageinduced diminution of free radical scavenging capacity in bee pollens and the contribution of constituent flavonoids. Journal of Agricultural and Food Chemistry 51, 742-745.

Campos, M.G.R., Bogdanov, S., Almeida-Muradian, L.B., Szczesna, T., Mancebo, Y., Frigerio, C., Ferreira, F., 2008. Pollen composition and standardisation of analytical methods. Journal of Apicultural Research and Bee World 47, 156-163.

Donadieu, Y., 1983. Le pollen: Thérapeutique Naturelle, sixth ed. Maloine, Paris, pp. 99.

Estevinho, L.M., Rodrigues, S., Pereira, A.P., Feás, X., 2012. Portuguese bee pollen: palynological study, nutritional and microbiological evaluation. International Journal of Food Science and Technology 47, 429-435.

Kall, M.A., 2003. Determination of total vitamin B6 in foods by isocratic HPLC: a comparison with microbiological analysis. Food Chemistry 82, 315-327.

Lahély, S., Bergaentzlé, M., Hasselmann, C., 1999. Fluorimetric determination of niacin in foods by high-performance liquid chromatography with post-column derivatization. Food Chemistry 65, 129-133.

Melo, I.L.P., Almeida-Muradian, L.B., 2010. Stability of antioxidants vitamins in bee pollen samples. Química Nova 33, 514-518.

Morais, M., Moreira, L., Feás, X., Estevinho, L.M., 2011. Honeybee-collected pollen from five Portuguese Natural Parks: palynological origin, phenolic content antioxidant properties and antimicrobial. Food and Chemical Toxicology 49, 1096-1101.

Moreira, L., Dias, L.G., Pereira, J.A., Estevinho, L.M., 2008. Antioxidant properties, total phenols and pollen analysis of propolis samples from Portugal. Food and Chemical Toxicology 46, 3482-3485.

Moreschi, E.C.P., 2006. Desenvolvimento e validação de métodos cromatográficos e avaliação da estabilidade de vitaminas hidrossolúveis em alimentos. PhD thesis, Faculdade de Ciências Farmacêuticas, Universidade de São Paulo, pp. 193.

Ollilainen, V., Vahteristo, L., Uusi-Rauva, A., Varo, P., Koivistoinen, P., Huttunen, J. 1993. The HPLC determination of total thiamin (vitamin $B_{1}$ ) in foods. Journal of Food Composition and Analysis 6, 152-165

Presoto, A.E.F., Almeida-Muradian, L.B., 2008. Validação de métodos cromatográficos por CLAE para análise das vitaminas $B_{1}, B_{2}, B_{6}$ e niacina naturalmente presentes em farinha de cereais. Química Nova 1, 498-502.

Sánchez, E.T., 2004. Polen: Producción Envasado y Comercialización. Diproansa, Mexico.

Stanley, R.G., Linskens, H.F., 1974. Pollen: Biology, Biochemistry, Management Springer-Verlag New York.

Szczesna, T., Rybak-Chmielewska, H., 1998. Some properties of honey bee collected pollen. In Polnisch-Deutsches Symposium Salus Apis Mellifera, new demands for honey bee breeding in the 21st century. Pszczelnicze Zeszyty Naukowe 42 79-80.

Torres, A., Guinand, J., Guerra Modernell, M., 2003. Propiedades nutricionales y estabilidad de los componentes de los alimentos. In: Guerra Modernell, M. (cood.), Efecto del procesamiento sobre la calidad nutricional de los alimentos, CYTED, Madrid. 